\title{
Impact of hyperthyroidism on cardiac hypertrophy
}

\author{
M L M Barreto-Chaves, N Senger, M R Fevereiro, A C Parletta and A P C Takano \\ Department of Anatomy, Institute of Biomedical Sciences, University of São Paulo, São Paulo, Brazil
}

Correspondence should be addressed to M L M Barreto-Chaves: mchaves@usp.br

\begin{abstract}
The cardiac growth process (hypertrophy) is a crucial phenomenon conserved across a wide array of species and is critically involved in the maintenance of cardiac homeostasis. This process enables an organism to adapt to changes in systemic demand and occurs due to a plethora of responses, depending on the type of signal or stimuli received. The growth of cardiac muscle cells in response to environmental conditions depends on the type, strength and duration of stimuli, and results in adaptive physiological responses or non-adaptive pathological responses. Thyroid hormones (TH) have a direct effect on the heart and induce a cardiac hypertrophy phenotype, which may evolve to heart failure. In this review, we summarize the literature on TH function in the heart by presenting results from experimental studies. We discuss the mechanistic aspects of $\mathrm{TH}$ associated with cardiac myocyte hypertrophy, increased cardiac myocyte contractility and electrical remodeling, as well as the associated signaling pathways. In addition to classical crosstalk with the sympathetic nervous system (SNS), emerging work pointing to the new endocrine interaction between TH and the renin-angiotensin system (RAS) is also explored. Given the inflammatory potential of the angiotensin II peptide, this new interaction may open the door for new therapeutic approaches which target the key mechanisms responsible for TH-induced cardiac hypertrophy.
\end{abstract}

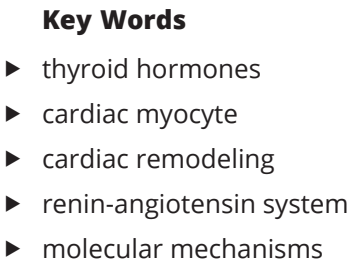

Endocrine Connections (2020) 9, R59-R69

\section{Introduction}

Thyroid hormones (TH) have a significant impact on the entire organism. However, it has been well documented that the heart is the main and the most important target of TH actions. Thus, variations in TH circulating levels are associated with the development and progression of cardiovascular diseases $(1,2,3,4)$. Cardiac hypertrophy, broadly defined as an enlargement of the heart, occurs as a consequence of high levels of $\mathrm{TH}$ and may predispose individuals to heart failure $(5,6,7,8)$. Cardiac hypertrophy, driven by $\mathrm{TH}$, is triggered by both direct action on cardiac cells and indirect mechanisms through interaction with other endocrine systems, such as the sympathetic nervous system (SNS) and the renin-angiotensin system (RAS) (9, 10) amongst others.

Accordingly, the importance of exploring the mechanistic aspects of $\mathrm{TH}$ action which lead to cardiac hypertrophy and its consequences for cardiac function, highlighting the molecular pathways involved in this process, in order to identify possible novel therapeutic targets, is clear. In this context, this review will describe the basic aspects of $\mathrm{TH}$ action, focusing on the molecular and cellular mechanisms associated with cardiac hypertrophy, and the contribution of the RAS as an important mediator of these effects.

\section{Thyroid hormones}

Triiodothyronine (T3) and thyroxine (T4) are the major TH produced by follicular cells of the thyroid gland, and they are bound to thyroglobulin protein until their release into the circulation. The synthesis of TH depends on the

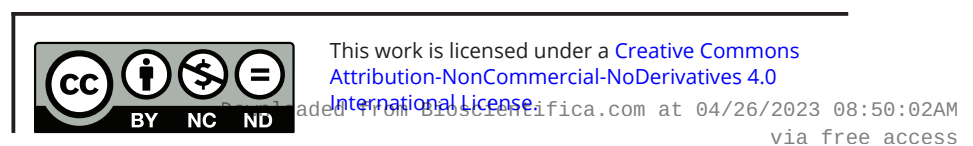


oxidation of dietary iodine, followed by iodination of tyrosine molecules and their coupling, forming $\mathrm{T} 3$ and $\mathrm{T} 4$. The main secreted hormone is T4, which is converted by deiodinases to $\mathrm{T} 3$ and other metabolites to act on virtually every cell of the organism, regulating basal metabolism and other important functions. Thyroid gland function is regulated by a classical negative feedback mechanism along the hypothalamus-pituitary-thyroid axis, where the hypothalamus produces thyrotropin-releasing hormone (TRH), which acts on the pituitary gland to promote thyroid stimulating hormone (TSH) release $(11,12,13)$. $\mathrm{TSH}$, in turn, binds to receptors on thyroid follicular cells promoting the production and release of $\mathrm{T} 4 / \mathrm{T} 3$ in the circulation. These hormones, when in their free form, act on receptors in the hypothalamus and the pituitary gland, balancing the production of TRH and TSH, and reducing the release of more TH $(14,15)$.

Although the thyroid gland is under strict regulatory control in the production and secretion of its hormones, there are conditions that can induce an imbalance of circulating TH levels. Graves' disease, TSH-secreting adenomas and toxic multinodular goiter are some examples of disorders that can lead to hyperthyroidism (16). In this context, overt hyperthyroidism is characterized by high levels of T3 and T4, and decreased TSH levels. However, the most usual type of hyperthyroidism observed in medical practice is the subclinical condition, characterized by decreased TSH associated with T3 and T4 levels within the reference values $(17,18)$. While overt hypothyroidism is characterized by elevated TSH levels and low circulating TH levels, subclinical hypothyroidism is diagnosed when TSH levels are elevated above the reference range but TH levels are normal. The etiology of both forms of hypothyroidism is most often caused by chronic autoimmune thyroiditis, therapies that destroy thyroid tissue and drugs that damage thyroid function (19).

From a mechanistic point of view, circulating $\mathrm{TH}$ reach their target tissues and cross the plasma membranes of cells through multiple tissue-specific transporters (20), such as monocarboxylate transporter 8 (MCT8) and 10 (MCT10), and proteins from the organic anion transporting polypeptide (OATP) family $(21,22,23,24)$. $\mathrm{T} 4$ is converted to $\mathrm{T} 3$, diiodothyronine (T2) or reverse T3 (rT3) by tissue deiodinases (D1, D2 or D3). D1 and D2 are responsible for the production of more than $70 \%$ of circulating T3 from T4 (25). D2 is located in the endoplasmic reticulum and is very active in the placenta, cardiac muscle and pituitary gland, where it helps to mediate the TSH production negative feedback loop $(26,27)$.
D1 is found in the plasma membrane of various cells and also catalyzes the formation of rT3 and T2 $(25,26)$. D3, in turn, is an enzyme normally expressed in the central nervous system (CNS) and placenta, and is found in the cellular plasma membrane; however, in ischemic situations D3 migrates to the nuclear membrane, where it inactivates $\mathrm{T} 4$ and T3, thereby reducing cellular metabolism $(28,29$, 30). Polymorphisms in these enzymes, or other diseases, may increase or reduce their activities, altering TH levels, and lead to systemic disorders $(31,32,33)$.

There are multiple mechanisms by which TH play their role on cells, some mechanisms cause effects within seconds or minutes, while other mechanisms which depend on gene transcription take longer (minutes to hours) $(34,35,36,37)$. Direct binding of TH to receptors located on mitochondria or in the cellular plasma membrane (e.g. integrin $\alpha \mathrm{V} \beta 3$ ) triggers the activation of intracellular signaling cascades and rapidly modulates the activity of ionic channels, although later effects on gene expression may result from the activation of these cascades $(38,39,40,41,42)$. Some of the effects of TH depend on binding to specific receptors for thyroid hormones (the thyroid hormone receptors (TR)), which can be located both in the cell cytoplasm and in the nucleus. When activated in the cytoplasm, the TH-TR complex interacts with kinases and phosphatases, and modulates their pathways, such as the PI3K pathway, without the need for DNA binding $(43,44)$.

Many of the actions triggered by TH occur in the cell nucleus and result from the binding of TH to TR, and the interaction of this complex with DNA to promote the expression of target genes. The canonical mechanism is T3 binding to TR: T3 is considered the predominant active form of TH because of its higher affinity for TR (ten-fold higher than T4) $(34,35,36)$. There are two known TR isoforms (TR- $\alpha$ and TR- $\beta$ ), which usually dimerize with steroid hormone receptors (such as retinoic acid receptor (RXR), forming the TR-RXR complex), or, to a lesser extent, as a homodimer $(45,46,47)$. These complexes have high affinity for specific DNA sequences called thyroid responsive elements (TRE) and remain attached to them, generally suppressing the expression of their target genes, whereas binding of $\mathrm{T} 3$ to this complex stimulates transcription $(48,49)$. However, the TH-TR complex may not require direct DNA connection to exert its effects; this complex can interact with transcription factors or other proteins associated with chromatin which, in turn, will promote the modulation of gene expression independent of direct TH-TR complex DNA binding. 
It is important to note that regardless of the mechanism of action, the combination of all the effects triggered by $\mathrm{TH}$ may activate several cellular pathways and determine different manifestations associated with cardiac dysfunction, for example, in the development of cardiac hypertrophy which precedes heart failure.

\section{Hyperthyroidism and the heart}

The main target of T3 is the heart, in which it promotes increased contractility and heart rate, leading to increased cardiac output. Thus, although hyperthyroidism induces a decrease in peripheral vascular resistance, its effect in raising cardiac output leads to the arterial hypertension frequently observed clinically. Such alterations contribute to a process of growth (cardiac hypertrophy), initially considered physiological or adaptive, which is critically involved in the maintenance of cardiac homeostasis and occurs as a result of increased cardiac demand. In this case, the cardiac hypertrophy observed in hyperthyroidism is characterized by: (1) ventricular wall thickening (concentric hypertrophy), due to the addition of sarcomeres in parallel within the cardiomyocyte; (2) increased contraction force, as a result of the modulation of pathways that tend to increase calcium uptake; and (3) increased relaxation velocity, due to increased calcium uptake by the sarcoplasmic reticulum during diastole. However, the long-term effects of $\mathrm{T} 3$ may result in cardiac hypertrophy as a consequence of dysfunction, also classified as pathological hypertrophy, which leads to cardiac remodeling and heart failure.

Although an increase in left ventricular mass has been observed in patients with hyperthyroidism, even with antithyroid treatment (50), a more recent study demonstrated that cardiovascular dysfunction associated with hyperthyroidism can be attenuated by treatment with antithyroid drugs and can be reversible after total thyroidectomy (51). In addition, the combination of antithyroid therapy and beta blockers, to control heart rate, prevents hemodynamic overload and cardiac remodeling leading to complete recovery from heart failure (52).

Supporting clinical findings, experimental data also demonstrated that antithyroid treatment significantly prevented the cardiac dysfunction induced by $\mathrm{T} 4$ in mice. In addition, the reversibility of cardiac pathology was also observed after 2 weeks of discontinuation of treatment with T4, including cardiac hypertrophy (53).

\section{TH in cardiac cells}

In cardiac tissue, TH exert their effects in cardiomyocytes, and other cardiac non-myocyte cells such as fibroblasts, endothelial cells, vascular smooth muscle cells and hematopoietic-derived cells. Cardiomyocytes correspond to two-thirds of the heart volume and express tenfold more TRs than fibroblasts (44), which make them more responsive to $\mathrm{TH}$ action and a protagonist of cardiac hypertrophy.

In cardiac fibroblasts, although $\mathrm{TH}$ increase the expression of TGF- $\beta 1$, a pro-fibrotic marker, TH also promote a decrease in type 1 collagen gene expression, the major fibrillar collagen in the heart $(54,55,56)$. In fact, different studies in the literature have shown that $\mathrm{TH}$ induce cardiac hypertrophy without increasing collagen deposition $(57,58,59)$. This antifibrotic role of $\mathrm{TH}$ is already well known, and the potential of these hormones as a alternative treatment for fibrosis in the heart has recently been studied $(55,60)$.

In the vasculature, $\mathrm{TH}$ act on both endothelial cells and smooth muscle cells, promoting an increase in the production of nitric oxide, a decrease in the proliferation of vascular smooth muscle cells and an improvement in angiogenesis $(43,61,62,63,64)$. In this way, TH modulate vascular remodeling and contribute to the maintenance of endothelial function.

It is important to note that, in the human and murine heart, approximately $5 \%$ of non-myocytes are hematopoietic-derived cells (65). Additionally, resident and recruited immune cells respond earlier to cardiac injury, and coordinate cardiomyocyte and non-cardiomyocyte responses during hypertrophy and remodeling (66). However, although some studies have investigated the effects of TH on various types of immune cells $(67,68,69)$, the impact of immune cells on the cardiac actions of $\mathrm{TH}$ remains to be clarified.

Regarding the role of $\mathrm{TH}$ at the cellular level in the context of cardiomyocyte hypertrophy, different mechanisms have been described in the literature. In general, these processes are triggered by the action of $\mathrm{TH}$, which lead to an increase in the expression of sarcoplasmic reticulum $\mathrm{Ca}^{2+}$-ATPase (SERCA2) and ryanodine receptors associated with a decrease in phospholamban, which results in faster systole and diastole (positive inotropism and lusotropism, respectively) $(8,70,71,72,73)$. Alpha myosin heavy chain $(\alpha-\mathrm{MHC})$ is upregulated by TH while beta myosin heavy chain ( $\beta$-MHC) is downregulated, which significantly enhances the contractile function of 
cardiac papillary muscle $(8,74,75,76)$. Additionally, actin and troponin I levels are also increased by TH in the heart (77) (Fig. 1). Interestingly, some of those TH-responsive genes are modulated by microRNAs (miR). Part of the decrease in $\beta$-MHC levels observed in hyperthyroidism is due to overexpression of miR-208a $(78,79,80)$ and miR-27a (81), while increased SERCA2 levels are regulated by miR-133 (82). In addition, TH increase the expression and activity of $\mathrm{Na}^{+} / \mathrm{K}^{+}$-ATPase channels and betaadrenergic receptors in cardiomyocytes, which leads to greater sensitivity of the heart to sympathetic stimulation, contributing to the positive inotropic effect $(77,83,84$, $85,86,87,88)$. These alterations may contribute to the tachycardia events and atrial fibrillation that are often associated with hyperthyroidism (89).

Moreover, diverse intracellular signaling pathways are rapidly activated by $\mathrm{T} 3$ and mediate cardiomyocyte growth, as occurs in the phosphoinositide 3-kinase/protein kinase $\mathrm{B} /$ mammalian target of rapamycin (PI3K/Akt/mTOR) signaling pathway (59, 90). These actions may also be triggered by membrane integrin $\alpha \mathrm{V} \beta 3$ (38), which has two TH binding sites: S1, which recognizes T3 and activates the PI3K pathway; and S2, which binds to both TH (despite having much higher affinity for T4) and activates the mitogen activated protein kinase (MAPK) pathway (40, 41, 42). Another important signaling pathway involved with TH-induced cardiomyocyte hypertrophy is adenosine mono phosphate-activated protein kinase (AMPK) signaling. AMPK is a sensor of intracellular adenosine nucleotide levels that is activated when ATP synthesis decreases and AMP or ADP levels increase. In response, AMPK activates catabolic pathways to generate more ATP and inhibits anabolic pathways, such as those involved in protein synthesis. In T3-treated cardiomyocytes, AMPK silencing induces increased hypertrophy, while AMPK stimulation

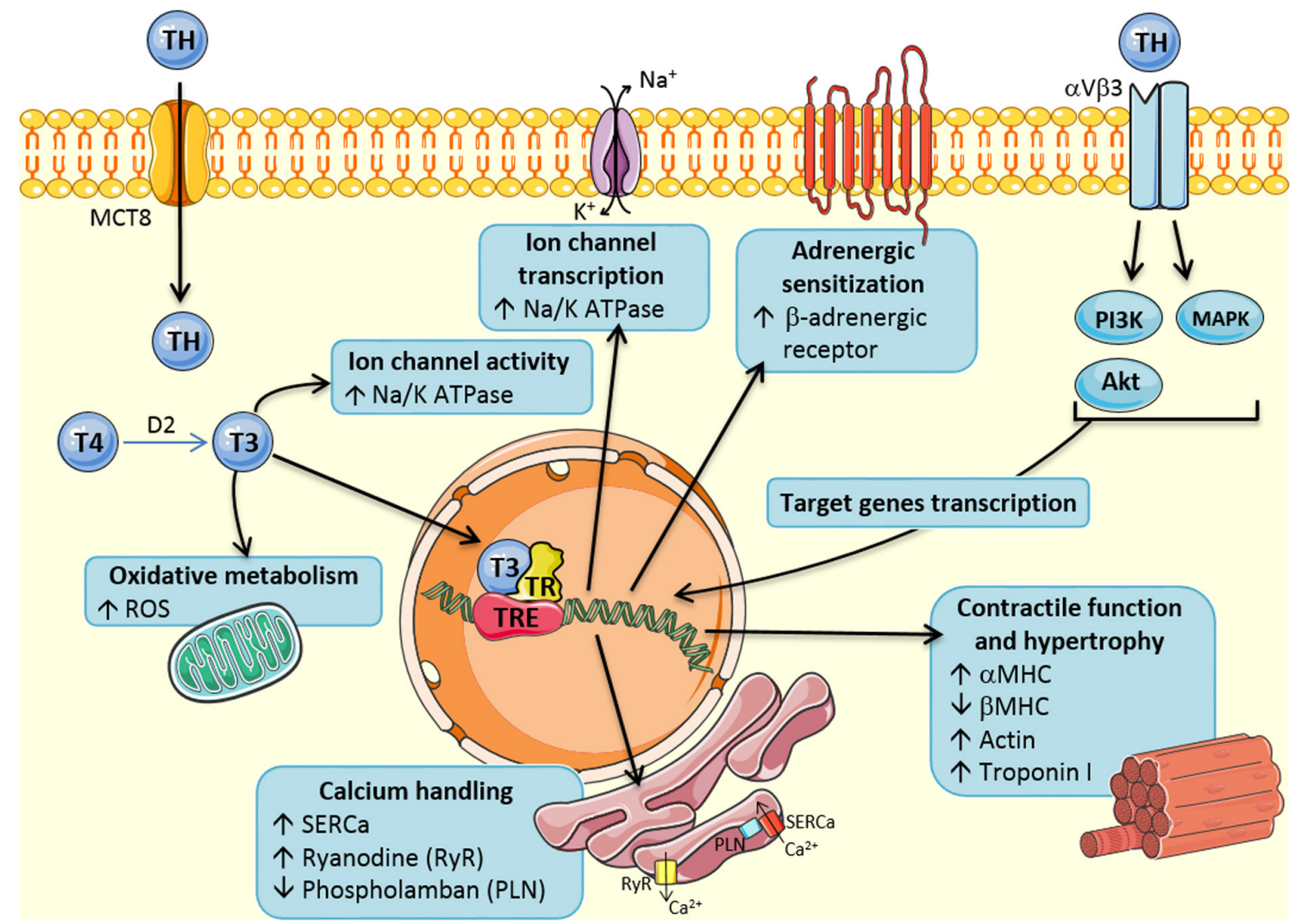

Figure 1

Some examples of thyroid hormones action on cardiomyocytes, which are upregulated in hyperthyroidism. Thyroid hormones (TH) might interact with cell surface receptors, such as integrin aVb3, to trigger the fast activation of cytoplasmic kinases, or it may enter the cell with the help of transporters such as MCT8. In the cytosol, much of T4 (tyroxine) is converted to T3 (triiodothyronine) by the action of the enzyme D2 (type 2 deiodinase). T3 then interacts with mitochondrial or cytoplasmatic receptors, affecting the activity of ion channels and the production of reactive oxygen species (ROS). This hormone also migrates to the nucleus and binds to thyroid hormone receptors (TR), forming a complex with high affinity for DNA-coupled thyroid response elements (TRE), although the T3-TR complex may interact with other DNA-bound proteins without the need to directly bind to chromatin to play its role. Thus, the transcription of several target genes is modulated, followed by protein synthesis, which ultimately results in cell hypertrophy.

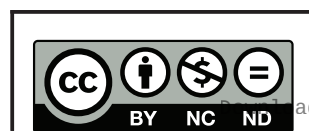

This work is licensed under a Creative Commons Attribution-NonCommercial-NoDerivatives 4.0 enternationab ticense.ifica.com at 04/26/2023 08:50:02AM 
attenuates this process (91), indicating its important cardioprotective role in hyperthyroid hearts.

Additionally, pathways involved in inflammation have also been related to the development of TH-induced cardiac hypertrophy. In this context, our group recently demonstrated that acute $\mathrm{T} 3$ treatment increased the expression of S100A8 (also known as calgranulin A), a calcium binding protein that when secreted to the extracellular space binds to toll-like 4 membrane receptors (TLR4), resulting in the recruitment of myeloid differentiation protein 88 (Myd88) and activation of nuclear factor- $\mathrm{kB}$ (NFkB). Inhibition of Myd88 and NFkB are able to attenuate cardiomyocyte hypertrophy, highlighting the involvement of this pathway in T3-induced hypertrophy (92).

The activation of inflammatory pathways is closely associated with cellular redox state. Regarding the heart, there is evidence which demonstrates increased free radical production and decreased mitochondrial antioxidant capacity in hyperthyroidism, resulting in cardiac oxidative stress $(93,94)$. The accumulation of reactive oxygen species (ROS) in the hyperthyroid heart seems to be crucial to the development of T3-induced cardiac hypertrophy, as antioxidant treatment with vitamin E attenuated cardiomyocyte growth (95).

While the activation of several pathways related to protein synthesis has been associated with the hypertrophic effects of $\mathrm{TH}$, proteolysis related pathways also appear to play an important role in this process. Recently, we have demonstrated increased expression of the proteasome in the hearts of hyperthyroid rats (96). Both catalytic (20SPT) and regulatory subunits (19SPT) of the constitutive proteasome, together with immunoproteasome subunits, were upregulated in rats treated with T3. Furthermore, ATP-dependent chymotrypsin-like activity (26SPT) was increased in cardiac tissue from hyperthyroid rats and in isolated cardiomyocytes treated with $\mathrm{T} 3$, which may be involved in the maintenance of protein quality control and the regulation of T3-induced cardiac hypertrophy (96).

\section{Interaction of TH with other endocrine systems}

Besides the direct actions of $\mathrm{TH}$ in the cardiomyocyte, cardiac hypertrophy induced by $\mathrm{T} 3$ is also a result of indirect effects of this hormone. An important contribution of the SNS has long been demonstrated in the development of tachycardia, increased force and velocity of cardiac contraction, and cardiac hypertrophy initiation in hyperthyroidism. Thus, it has been demonstrated that treatment with the beta-adrenergic blocker propranolol inhibited T3-induced cardiac hypertrophy and increased heart rate (10). Plasma and urine levels of catecholamines are not altered in hyperthyroidism, which indicate that some $\mathrm{T} 3$ effects are mediated by an increased responsiveness and sensitivity of cardiac tissue to sympathomimetic stimuli (97). This increased sympathetic sensitivity is due to an increase in the number of adrenergic receptors in the hyperthyroid heart (98). Thus, the administration of a beta-adrenergic receptor antagonist to patients with hyperthyroidism is often used by clinicians to attenuate heart rate, systolic blood pressure and other cardiovascular manifestations $(18,99)$. However, in some cases the use of beta-adrenergic antagonists is contraindicated, which demonstrates the need for new therapeutic targets.

In addition to the increased cardiac beta-adrenergic sensitivity observed in hyperthyroidism, the RAS has been recognized in the last two decades as a significant mediator of the cardiovascular actions of $\mathrm{TH}$, and our studies have contributed to the understanding of the crosstalk between $\mathrm{TH}$ and the RAS. The RAS is an important endocrine regulator of cardiovascular homeostasis, classically acting in the control of blood pressure and extracellular fluid volume (100). Alterations in the levels of peptides that constitute the RAS are closely related to cardiovascular function impairment, and for this reason several members of the RAS have been used as a target for the development of therapeutic drugs.

In the classical RAS, renin (an aspartyl protease produced in juxtaglomerular cells) forms angiotensin I (Ang I) by cleavage of the N-terminal portion of hepatic angiotensinogen (AGT). Ang I is converted into angiotensin II (Ang II) by the action of ACE (Ang I converting enzyme), an endothelial peptidase which removes two C-terminal amino acids $(101,102)$. Ang II is an octapeptide which binds to two specific G-protein-coupled receptors, AT1R and AT2R, to perform its biological activity, as illustrated in Fig. 2.

Although the RAS has been considered as an endocrine system dependent on renal renin, over the years accumulating evidence suggests that different tissues are able to locally synthesize some of the RAS components, including Ang II (103). In fact, it has been demonstrated that AGT, ACE, AT1R and AT2R are expressed in the heart, enabling the local synthesis and action of Ang II in this organ $(104,105,106)$. In addition, it is important to emphasize that most cardiac Ang I and Ang II peptides

This work is licensed under a Creative Commons Attribution-NonCommercial-NoDerivatives 4.0 Internationab kicense.ifica, com at 04/26/2023 08:50:02AM 


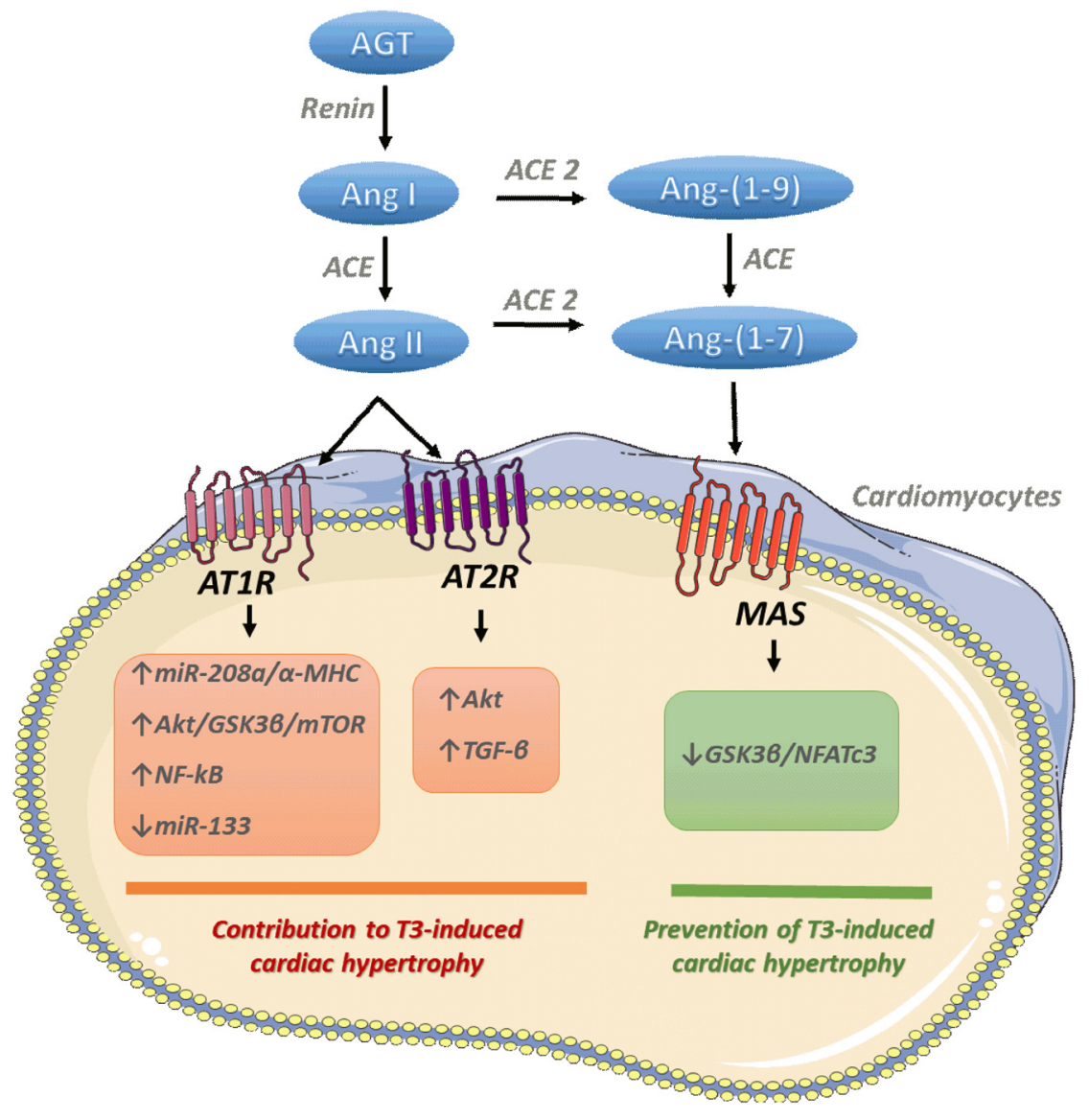

\section{Figure 2}

Involvement of the RAS in cardiac hypertrophy induced by TH. AT1R activation triggers TH-mediated cardiac hypertrophy by activating the miR-208a/ $\alpha$-MHC, Akt/GSK3 $\beta / m T O R$ and NFkB pathways, and by downregulating miR-133. Additionally, AT2R contributes to cardiac growth in hyperthyroid rats by participating in Akt and TGF- $\beta$ activation. Increased levels of Ang-(1-7) prevents the development of T3-induced cardiac hypertrophy by blocking GSK3/NFATc3 activation via the MAS receptor. AGT, angiotensinogen; Ang I, angiotensin I; Ang II, angiotensin II; Ang-(1-9), angiotensin-(1-9); Ang-(1-7), angiotensin-(1-7); ACE, angiotensin I converting enzyme; ACE2, angiotensin II converting enzyme; AT1R, angiotensin II receptor type 1; AT2R, angiotensin II receptor type 2 . are produced locally rather than derived from the blood, indicating that this endocrine system is clinically relevant (107).

$\mathrm{TH}$ regulate the activity of the RAS in different tissues, and therefore several studies have been conducted to understand the crosstalk between these two endocrine systems, especially in thyroid gland disorders $(9,108)$. In this context, experimental hyperthyroidism is associated with increased levels of renin, Ang II, AT1R and AT2R in the heart $(109,110,111,112)$. Additionally, it has been shown that a critical RAS contribution to cardiac hypertrophy is observed in hyperthyroidism, as the inhibition of Ang II activity by AT1R/AT2R blockers or ACE inhibition totally prevents the development of cardiac hypertrophy in vivo and in vitro $(10,51,110,113$, 114, 115, 116, 117). AT1R silencing using a siRNA or AT1R blockade with a pharmacological antagonist (losartan) completely abolished TH-induced activation of the miR-208a/ $\alpha-M H C$, Akt/GSK3 $\beta /$ mTOR and NFkB signaling pathways, together with the downregulation of miR-133. These mechanisms have been shown to play a key role in the development of T3-induced cardiac hypertrophy (78, 82, 59, 92, 116). Concerning AT2R, Carneiro-Ramos and collaborators demonstrated that blockage of this receptor also prevents TH-mediated cardiac hypertrophy in vivo and in vitro, by preventing Akt activation (117) (Fig. 2). Furthermore, TH increase transforming growth factor beta (TGF- $\beta$ ) expression in cardiac tissue by AT2R stimulation, which may be involved in TH-mediated cardiac hypertrophy (58) (Fig. 2).

In addition to the peptides previously described, in the late 1980s the classical view of the RAS was expanded after discovering a new heptapeptide, angiotensin-(1-7) (Ang(1-7)), which activates the G-protein-coupled receptor MAS (118, 119). Ang-(1-7) is formed from Ang II by the enzymatic action of the carboxypeptidase ACE2 (Ang II converting enzyme) or from Ang I by an ACE-independent pathway $(120,121,122)$ (Fig. 2). In the hyperthyroid state, an upregulation of Ang-(1-7), ACE2 activity and the MAS receptor in the heart was demonstrated, with no changes in the plasma levels of Ang-(1-7) (123). Contributing to these data, recently it was shown that elevated circulating levels of Ang-(1-7) prevented T3-induced cardiac hypertrophy by attenuating the glycogen synthase kinase 3 beta/nuclear factor of activated T-cells (GSK3 $\beta /$ NFATc3) signaling pathway (124) (Fig. 2). (c) 2020 The authors Published by Bioscientifica Ltd
This work is licensed under a Creative Commons Attribution-NonCommercial-NoDerivatives 4.0 Internationab sicense.ifica . com at 04/26/2023 08:50:02AM 
Considering that cardiac hypertrophy may represent an important risk factor for the progression of cardiovascular disease, understanding the crosstalk between the RAS and TH is clearly clinically important; new pharmacological tools to reduce the cardiac complications observed in hyperthyroidism are required, especially in patients in whom beta-adrenergic antagonists are contraindicated.

\section{Conclusion and future perspectives}

Several key mediators of TH-induced cardiac hypertrophy have been identified from animal studies. However, despite significant progress in understanding the molecular mechanisms that accompany TH-induced cardiac hypertrophy, further studies are required in order to understand the complex level of communication between $\mathrm{TH}$ and other systems. In this context, the influence of hypoxia in the microenvironment of TH-induced cardiac hypertrophy and the crosstalk between $\mathrm{TH}$, hypoxia and inflammation signaling remain to be clarified, as does the potential role of $\mathrm{TH}$ in the early and long-term cardiac angiogenesis process.

\section{Declaration of interest}

The authors declare that there is no conflict of interest that could be perceived as prejudicing the impartiality of this review.

\section{Funding}

This work was supported by São Paulo Research Foundation (FAPESP grant numbers: 2016/13896-0), National Council of Scientific and Technological Development (CNPq - grants number: 305182/2014-5 and 302022/2019-8) and Coordenação de Aperfeiçoamento de Pessoal de Nível Superior - Brasil (CAPES) - Finance Code 001. Part of this manuscript was previously presented at the 21st Congress of European Society of Endocrinology in Lyon, France.

\section{References}

1 Graettinger JS, Muenster JJ, Selverstone LA \& Campbell JA. A correlation of clinical and hemodynamic studies in patients with hyperthyroidism with and without congestive heart failure. Journal of Clinical Investigation 195938 1316-1327. (https://doi.org/10.1172/ JCI103906)

2 Nixon JV, Anderson RJ \& Cohen ML. Alterations in left ventricular mass and performance in patients treated effectively for thyrotoxicosis. A comparative echocardiographic study. American Journal of Medicine 197967 268-276. (https://doi.org/10.1016/00029343(79)90402-9)

3 Kapitola J \& Vilimovská D. Inhibition of the early circulatory effects of triiodothyronine in rats by propranolol. Physiologia Bohemoslovaca 1981 30 347-351. (available at: http://europepmc.org/abstract/med/6458055)

4 Klein I. Thyroid hormone and the cardiovascular system. American Journal of Medicine 199088 631-637. (https://doi.org/10.1016/00029343(90)90531-H)
5 Boccalandro C, Boccalandro F, Orlander P \& Wei CF. Severe reversible dilated cardiomyopathy and hyperthyroidism: case report and review of the literature. Endocrine Practice 20039 140-146. (https://doi. org/10.4158/EP.9.2.140)

6 Siu CW, Yeung CY, Lau CP, Kung AW \& Tse HF. Incidence, clinical characteristics and outcome of congestive heart failure as the initial presentation in patients with primary hyperthyroidism. Heart 2007 93 483-487. (https://doi.org/10.1136/hrt.2006.100628)

7 Ismail HM. Reversible pulmonary hypertension and isolated rightsided heart failure associated with hyperthyroidism. Journal of General Internal Medicine 200722 148-150. (https://doi.org/10.1007/ s11606-006-0032-0)

8 Dillmann W. Cardiac hypertrophy and thyroid hormone signaling. Heart Failure Reviews 201015 125-132. (https://doi.org/10.1007/ s10741-008-9125-7)

9 Barreto-Chaves ML, Carrillo-Sepúlveda MA, Carneiro-Ramos MS, Gomes DA \& Diniz GP. The crosstalk between thyroid hormones and the renin-angiotensin system. Vascular Pharmacology 201052 166-170. (https://doi.org/10.1016/j.vph.2009.10.009)

$10 \mathrm{Hu}$ LW, Benvenuti LA, Liberti EA, Carneiro-Ramos MS \& BarretoChaves ML. Thyroxine-induced cardiac hypertrophy: influence of adrenergic nervous systems versus renin-angiotensin system on myocyte remodeling. American Journal of Physiology: Regulatory, Integrative and Comparative Physiology 2003285 R1473-R1480. (https://doi.org/10.1152/ajpregu.00269.2003)

11 Greer MA. Evidence of hypothalamic control of the pituitary release of thyrotropin. Proceedings of the Society for Experimental Biology and Medicine 195177 603-608. (https://doi.org/10.3181/00379727-7718862)

12 Schally AV, Redding TW, Bowers CY \& Barrett JF. Isolation and properties of porcine thyrotropin-releasing hormone. Journal of Biological Chemistry 1969244 4077-4088.

13 Martin JB \& Reichlin S. Thyrotrophin secretion in rats after hypothalamic electrical stimulation or injection of synthetic TSH-releasing factor. Science 1970168 1366-1368. (https://doi. org/10.1126/science.168.3937.1366)

14 Knigge KM. Neural regulation of TSH secretion: effect of diencephalic lesions and intracerebral injection of thyroxin and thyrotropin upon thyroid activity in the cat. Major Problems in Neuroendocrinology 1964 261-285. (https://doi.org/10.1159/000390083)

15 Davies AG. Thyroid physiology. BMJ 19722 206-209. (https://doi. org/10.1136/bmj.2.5807.206)

16 Jabbar A, Pingitore A, Pearce SH, Zaman A, Iervasi G \& Razvi S. Thyroid hormones and cardiovascular disease. Nature Reviews: Cardiology 201714 39-55. (https://doi.org/10.1038/ nrcardio.2016.174)

17 Surks MI, Ortiz E, Daniels GH, Sawin CT, Col NF, Cobin RH, Franklyn JA, Hershman JM, Burman KD, Denke MA, et al. Subclinical thyroid disease: scientific review and guidelines for diagnosis and management. JAMA 2004291 228-238. (https://doi.org/10.1001/ jama.291.2.228)

18 Bahn RS, Burch HB, Cooper DS, Garber JR, Greenlee MC, Klein I, Laurberg P, McDougall IR, Montori VM, Rivkees SA, et al. Hyperthyroidism and other causes of thyrotoxicosis: management guidelines of the American Thyroid Association and American Association of Clinical Endocrinologists. Endocrine Practice 201117 456-520. (https://doi.org/10.4158/ep.17.3.456)

19 Biondi B \& Cooper DS. The clinical significance of subclinical thyroid dysfunction. Endocrine Reviews 200829 76-131. (https://doi. org/10.1210/er.2006-0043)

20 Abe T, Suzuki T, Unno M, Tokui T \& Ito S. Thyroid hormone transporters: recent advances. Trends in Endocrinology and Metabolism 200213 215-220. (https://doi.org/10.1016/s1043-2760(02)00599-4)

21 Abe T, Kakyo M, Sakagami H, Tokui T, Nishio T, Tanemoto M, Nomura H, Hebert SC, Matsuno S, Kondo H, et al. Molecular characterization and tissue distribution of a new organic anion 
transporter subtype (oatp3) that transports thyroid hormones and taurocholate and comparison with oatp2. Journal of Biological Chemistry 1998273 22395-22401. (https://doi.org/10.1074/ jbc.273.35.22395)

22 Friesema EC, Docter R, Moerings EP, Stieger B, Hagenbuch B, Meier PJ, Krenning EP, Hennemann G \& Visser TJ. Identification of thyroid hormone transporters. Biochemical and Biophysical Research Communications 1999254 497-501. (https://doi.org/10.1006/ bbrc.1998.9974)

23 Friesema EC, Ganguly S, Abdalla A, Manning Fox JE, Halestrap AP \& Visser TJ. Identification of monocarboxylate transporter 8 as a specific thyroid hormone transporter. Journal of Biological Chemistry 2003278 40128-40135. (https://doi.org/10.1074/jbc.M300909200)

24 Friesema EC, Jansen J, Jachtenberg JW, Visser WE, Kester MH \& Visser TJ. Effective cellular uptake and efflux of thyroid hormone by human monocarboxylate transporter 10. Molecular Endocrinology 200822 1357-1369. (https://doi.org/10.1210/me.2007-0112)

25 Köhrle J. Local activation and inactivation of thyroid hormones: the deiodinase family. Molecular and Cellular Endocrinology 1999151 103-119. (https://doi.org/10.1016/s0303-7207(99)00040-4)

26 Baqui MM, Gereben B, Harney JW, Larsen PR \& Bianco AC. Distinct subcellular localization of transiently expressed types 1 and 2 iodothyronine deiodinases as determined by immunofluorescence confocal microscopy. Endocrinology 2000141 4309-4312. (https:// doi.org/10.1210/endo.141.11.7872)

27 Schneider MJ, Fiering SN, Pallud SE, Parlow AF, St Germain DL \& Galton VA. Targeted disruption of the type 2 selenodeiodinase gene $\left(\mathrm{DIO}_{2}\right)$ results in a phenotype of pituitary resistance to T4. Molecular Endocrinology 200115 2137-2148. (https://doi.org/10.1210/ mend.15.12.0740)

28 Baqui M, Botero D, Gereben B, Curcio C, Harney JW, Salvatore D, Sorimachi K, Larsen PR \& Bianco AC. Human type 3 iodothyronine selenodeiodinase is located in the plasma membrane and undergoes rapid internalization to endosomes. Journal of Biological Chemistry 2003278 1206-1211. (https://doi.org/10.1074/jbc.M210266200)

29 Simonides WS, Mulcahey MA, Redout EM, Muller A, Zuidwijk MJ, Visser TJ, Wassen FW, Crescenzi A, da-Silva WS, Harney J, et al. Hypoxia-inducible factor induces local thyroid hormone inactivation during hypoxic-ischemic disease in rats. Journal of Clinical Investigation 2008118 975-983. (https://doi.org/10.1172/JCI32824)

30 Jo S, Kalló I, Bardóczi Z, Arrojo e Drigo R, Zeöld A, Liposits Z, Oliva A, Lemmon VP, Bixby JL, Gereben B, et al. Neuronal hypoxia induces hsp40-mediated nuclear import of type 3 deiodinase as an adaptive mechanism to reduce cellular metabolism. Journal of Neuroscience 201232 8491-8500. (https://doi.org/10.1523/ JNEUROSCI.6514-11.2012)

31 Verloop H, Dekkers OM, Peeters RP, Schoones JW \& Smit JW. Genetics in endocrinology: genetic variation in deiodinases: a systematic review of potential clinical effects in humans. European Journal of Endocrinology 2014171 R123-R135. (https://doi. org/10.1530/EJE-14-0302)

32 Gereben B, Zavacki AM, Ribich S, Kim BW, Huang SA, Simonides WS, Zeöld A \& Bianco AC. Cellular and molecular basis of deiodinaseregulated thyroid hormone signaling. Endocrine Reviews 200829 898-938. (https://doi.org/10.1210/er.2008-0019)

33 Bianco AC, Salvatore D, Gereben B, Berry MJ \& Larsen PR. Biochemistry, cellular and molecular biology, and physiological roles of the iodothyronine selenodeiodinases. Endocrine Reviews 200223 38-89. (https://doi.org/10.1210/edrv.23.1.0455)

34 Tata JR \& Widnell CC. Ribonucleic acid synthesis during the early action of thyroid hormones. Biochemical Journal 196698 604-620. (https://doi.org/10.1042/bj0980604)

35 Oppenheimer JH, Koerner D, Schwartz HL \& Surks MI. Specific nuclear triiodothyronine binding sites in rat liver and kidney. Journal of Clinical Endocrinology and Metabolism 197235 330-333. (https:// doi.org/10.1210/jcem-35-2-330)
36 Samuels HH \& Tsai JS. Thyroid hormone action in cell culture: demonstration of nuclear receptors in intact cells and isolated nuclei. PNAS 197370 3488-3492. (https://doi.org/10.1073/pnas.70.12.3488)

37 Flamant F, Cheng SY, Hollenberg AN, Moeller LC, Samarut J, Wondisford FE, Yen PM \& Refetoff S. Thyroid hormone signaling pathways: time for a more precise nomenclature. Endocrinology 2017 158 2052-2057. (https://doi.org/10.1210/en.2017-00250)

38 Bergh JJ, Lin HY, Lansing L, Mohamed SN, Davis FB, Mousa S \& Davis PJ. Integrin alphaVbeta3 contains a cell surface receptor site for thyroid hormone that is linked to activation of mitogen-activated protein kinase and induction of angiogenesis. Endocrinology 2005 146 2864-2871. (https://doi.org/10.1210/en.2005-0102)

39 Incerpi S, Luly P, De Vito P \& Farias RN. Short-term effects of thyroid hormones on the $\mathrm{Na} / \mathrm{H}$ antiport in L-6 myoblasts: high molecular specificity for 3,3,5-triiodo-l-thyronine. Endocrinology 1999140 683-689. (https://doi.org/10.1210/endo.140.2.6535)

40 Cody V, Davis PJ \& Davis FB. Molecular modeling of the thyroid hormone interactions with av $\beta 3$ integrin. Steroids 200772 165-170. (https://doi.org/10.1016/j.steroids.2006.11.008)

41 Lin HY, Davis FB, Gordinier JK, Martino LJ \& Davis PJ. Thyroid hormone induces activation of mitogen-activated protein kinase in cultured cells. American Journal of Physiology 1999276 C1014-C1024. (https://doi.org/10.1152/ajpcell.1999.276.5.C1014)

42 Shih A, Lin HY, Davis FB \& Davis PJ. Thyroid hormone promotes serine phosphorylation of $\mathrm{p} 53$ by mitogen-activated protein kinase. Biochemistry 200140 2870-2878. (https://doi.org/10.1021/ bi001978b)

43 Carrillo-Sepúlveda MA, Ceravolo GS, Fortes ZB, Carvalho MH, Tostes RC, Laurindo FR, Webb RC \& Barreto-Chaves ML. Thyroid hormone stimulates NO production via activation of the PI3K/ Akt pathway in vascular myocytes. Cardiovascular Research 201085 560-570. (https://doi.org/10.1093/cvr/cvp304)

44 Dillmann WH. Cellular action of thyroid hormone on the heart. Thyroid 200212 447-452. (https://doi. org/10.1089/105072502760143809)

45 Yu VC, Delsert C, Andersen B, Holloway JM, Devary OV, Näär AM, Kim SY, Boutin JM, Glass CK \& Rosenfeld MG. RXR beta: a coregulator that enhances binding of retinoic acid, thyroid hormone, and vitamin D receptors to their cognate response elements. Cell 199167 1251-1266. (https://doi.org/10.1016/0092-8674(91)90301-e)

46 Forman BM, Casanova J, Raaka BM, Ghysdael J \& Samuels HH. Half-site spacing and orientation determines whether thyroid hormone and retinoic acid receptors and related factors bind to DNA response elements as monomers, homodimers, or heterodimers. Molecular Endocrinology 19926 429-442. (https://doi.org/10.1210/ mend.6.3.1316541)

47 Lazar MA, Berrodin TJ \& Harding HP. Differential DNA binding by monomeric, homodimeric, and potentially heteromeric forms of the thyroid hormone receptor. Molecular and Cellular Biology 199111 5005-5015. (https://doi.org/10.1128/mcb.11.10.5005)

48 Umesono K, Murakami KK, Thompson CC \& Evans RM. Direct repeats as selective response elements for the thyroid hormone, retinoic acid, and vitamin D3 receptors. Cell 199165 1255-1266. (https://doi.org/10.1016/0092-8674(91)90020-y)

49 Graupner G, Wills KN, Tzukerman M, Zhang XK \& Pfahl M. Dual regulatory role for thyroid-hormone receptors allows control of retinoic-acid receptor activity. Nature 1989340 653-656. (https://doi. org/10.1038/340653a0)

50 Marcisz C, Jonderko G, Wróblewski T, Kurzawska G \& Mazur F. Left ventricular mass in patients with hyperthyroidism. Medical Science Monitor 200612 CR481-6.

51 Muthukumar S, Sadacharan D, Ravikumar K, Mohanapriya G, Hussain Z \& Suresh RV. A prospective study on cardiovascular dysfunction in patients with hyperthyroidism and its reversal after surgical cure. World Journal of Surgery 201640 622-628. (https://doi. org/10.1007/s00268-015-3352-6) 
52 Oliveros-Ruiz L, Vallejo M, Diez Canseco LF, Cárdenas M \& Hermosillo JA. Determinants of thyrotoxic cardiomyopathy recovery. BioMed Research International 20132013 452709. (https://doi. org/10.1155/2013/452709)

53 Saad NS, Repas SJ, Floyd K, Janssen PML \& Elnakish MT. Recovery following thyroxine treatment withdrawal, but not propylthiouracil, averts in vivo and ex vivo thyroxine-provoked cardiac complications in adult FVB/mice. BioMed Research International 201720176071031. (https://doi.org/10.1155/2017/6071031)

54 Yao J \& Eghbali M. Decreased collagen gene expression and absence of fibrosis in thyroid hormone-induced myocardial hypertrophy. Response of cardiac fibroblasts to thyroid hormone in vitro. Circulation Research 199271 831-839. (https://doi.org/10.1161/01. res.71.4.831)

55 Zhang K, Tang YD, Zhang Y, Ojamaa K, Li Y, Saini AS, CarrilloSepulveda MA, Rajagopalan V \& Gerdes AM. Comparison of therapeutic triiodothyronine versus metoprolol in the treatment of myocardial infarction in rats. Thyroid 201828 799-810. (https://doi. org/10.1089/thy.2017.0544)

56 Weltman NY, Pol CJ, Zhang Y, Wang Y, Koder A, Raza S, Zucchi R, Saba A, Colligiani D \& Gerdes AM. Long-term physiological T3 supplementation in hypertensive heart disease in rats. American Journal of Physiology: Heart and Circulatory Physiology 2015309 H1059-H1065. (https://doi.org/10.1152/ajpheart.00431.2015)

57 Chen WJ, Lin KH \& Lee YS. Molecular characterization of myocardial fibrosis during hypothyroidism: evidence for negative regulation of the pro-alpha1(I) collagen gene expression by thyroid hormone receptor. Molecular and Cellular Endocrinology 2000162 45-55. (https://doi.org/10.1016/s0303-7207(00)00203-3)

58 Diniz GP, Carneiro-Ramos MS \& Barreto-Chaves ML. Angiotensin type 1 (AT1) and type 2 (AT2) receptors mediate the increase in TGF-beta1 in thyroid hormone-induced cardiac hypertrophy. Pflugers Archiv 2007454 75-81. (https://doi.org/10.1007/s00424006-0192-0)

59 Diniz GP, Carneiro-Ramos MS \& Barreto-Chaves ML. Angiotensin type 1 receptor mediates thyroid hormone-induced cardiomyocyte hypertrophy through the Akt/GSK-3beta/mTOR signaling pathway. Basic Research in Cardiology 2009104 653-667. (https://doi. org/10.1007/s00395-009-0043-1)

60 Bano A, Chaker L, Muka T, Mattace-Raso FUS, Bally L, Franco OH, Peeters RP \& Razvi S. Thyroid function and the risk of fibrosis of the liver, heart and lung in humans: a systematic review and meta-analysis. Thyroid 2020 [epub]. (https://doi.org/10.1089/ thy.2019.0572)

61 Ichiki T. Thyroid hormone and vascular remodeling. Journal of Atherosclerosis and Thrombosis 201623 266-275. (https://doi. org $/ 10.5551 /$ jat.32755)

62 McAllister RM, Grossenburg VD, Delp MD \& Laughlin MH. Effects of hyperthyroidism on vascular contractile and relaxation responses. American Journal of Physiology 1998274 E946-E953. (https://doi. org/10.1152/ajpendo.1998.274.5.E946)

63 Anjos-Ramos L, Carneiro-Ramos MS, Diniz GP, Martins-Silva J \& Barreto-Chaves ML. Early cardiac hypertrophy induced by thyroxine is accompanied by an increase in VEGF-A expression but not by an increase in capillary density. Virchows Archiv 2006448 472-479. (https://doi.org/10.1007/s00428-005-0140-y)

64 Tomanek RJ \& Busch TL. Coordinated capillary and myocardial growth in response to thyroxine treatment. Anatomical Record 1998251 44-49. (https://doi.org/10.1002/(SICI)10970185(199805)251:1<44::AID-AR8>3.0.CO;2-E)

65 Pinto AR, Ilinykh A, Ivey MJ, Kuwabara JT, D'Antoni ML, Debuque R, Chandran A, Wang L, Arora K, Rosenthal NA, et al. Revisiting cardiac cellular composition. Circulation Research 2016118 400-409. (https://doi.org/10.1161/CIRCRESAHA.115.307778)

66 Frieler RA \& Mortensen RM. Immune cell and other noncardiomyocyte regulation of cardiac hypertrophy and remodeling.
Circulation 2015131 1019-1030. (https://doi.org/10.1161/ CIRCULATIONAHA.114.008788)

67 De Vito P, Incerpi S, Pedersen JZ, Luly P, Davis FB \& Davis PJ. Thyroid hormones as modulators of immune activities at the cellular level. Thyroid 201121 879-890. (https://doi.org/10.1089/thy.2010.0429)

68 De Vito P, Balducci V, Leone S, Percario Z, Mangino G, Davis PJ, Davis FB, Affabris E, Luly P, Pedersen JZ, et al. Nongenomic effects of thyroid hormones on the immune system cells: new targets, old players. Steroids 201277 988-995. (https://doi.org/10.1016/j. steroids.2012.02.018)

69 Van der Spek AH, Fliers E \& Boelen A. Thyroid hormone metabolism in innate immune cells. Journal of Endocrinology 2017232 R67-R81. (https://doi.org/10.1530/JOE-16-0462)

70 Rohrer D \& Dillmann WH. Thyroid hormone markedly increases the mRNA coding for sarcoplasmic reticulum Ca2+ATPase in the rat heart. Journal of Biological Chemistry 1988263 6941-6944.

71 Arai M, Otsu K, MacLennan DH, Alpert NR \& Periasamy M. Effect of thyroid hormone on the expression of mRNA encoding sarcoplasmic reticulum proteins. Circulation Research 199169 266-276. (https:// doi.org/10.1161/01.res.69.2.266)

72 Kiss E, Jakab G, Kranias EG \& Edes I. Thyroid hormone induced alterations in phospholamban protein expression: regulatory effects on sarcoplasmic reticulum Ca2+ transport and myocardial relaxation. Circulation Research 199475 245-251. (https://doi.org/10.1161/01. res.75.2.245)

73 Ojamaa K, Kenessy A \& Klein I. Thyroid hormone regulation of phospholamban phosphorylation in the rat heart. Endocrinology 2000 141 2139-2144. (https://doi.org/10.1210/endo.141.6.7514)

74 Morkin E. Regulation of myosin heavy chain genes in the heart. Circulation 199387 1451-1460. (https://doi.org/10.1161/01. cir.87.5.1451)

75 Lompre AM, Nadal-Ginard B \& Mahdavi V. Expression of the cardiac ventricular alpha- and beta-myosin heavy chain genes is developmentally and hormonally regulated. Journal of Biological Chemistry 1984259 6437-6446.

76 Balkman C, Ojamaa K \& Klein I. Time course of the in vivo effects of thyroid hormone on cardiac gene expression. Endocrinology 1992130 2001-2006. (https://doi.org/10.1210/endo.130.4.1312435)

77 Kahaly GJ \& Dillmann WH. Thyroid hormone action in the heart. Endocrine Reviews 200526 704-728. (https://doi.org/10.1210/er.20030033)

78 Diniz GP, Takano AP \& Barreto-Chaves ML. MiRNA-208a and miRNA$208 \mathrm{~b}$ are triggered in thyroid hormone-induced cardiac hypertrophy - role of type 1 angiotensin II receptor (AT1R) on miRNA-208a/oMHC modulation. Molecular and Cellular Endocrinology 2013374 117-124. (https://doi.org/10.1016/j.mce.2013.04.010)

79 Van Rooij E, Sutherland LB, Qi X, Richardson JA, Hill J \& Olson EN. Control of stress-dependent cardiac growth and gene expression by a microRNA. Science 2007316 575-579. (https://doi.org/10.1126/ science.1139089)

80 Callis TE, Pandya K, Seok HY, Tang RH, Tatsuguchi M, Huang ZP, Chen JF, Deng Z, Gunn B, Shumate J, et al. MicroRNA-208a is a regulator of cardiac hypertrophy and conduction in mice. Journal of Clinical Investigation 2009119 2772-2786. (https://doi.org/10.1172/ JCI36154)

81 Nishi H, Ono K, Horie T, Nagao K, Kinoshita M, Kuwabara Y, Watanabe S, Takaya T, Tamaki Y, Takanabe-Mori R, et al. MicroRNA27 a regulates $\beta$ cardiac myosin heavy chain gene expression by targeting thyroid hormone receptor $\beta 1$ in neonatal rat ventricular myocytes. Molecular and Cellular Biology 201131 744-755. (https:// doi.org/10.1128/MCB.00581-10)

82 Diniz GP, Lino CA, Guedes EC, Moreira Ldo N \& Barreto-Chaves ML. Cardiac micro-RNA-133 is down-regulated in thyroid hormonemediated cardiac hypertrophy partially via type 1 angiotenin II receptor. Basic Research in Cardiology 2015110 49. (https://doi. org/10.1007/s00395-015-0504-7) 
83 Williams LT, Lefkowitz RJ, Watanabe AM, Hathaway DR \& Besch Jr HR. Thyroid hormone regulation of beta-adrenergic receptor number. Journal of Biological Chemistry 1977252 2787-2789.

84 Yalcin Y, Carman D, Shao Y, Ismail-Beigi F, Klein I \& Ojamaa K. Regulation of Na/K-ATPase gene expression by thyroid hormone and hyperkalemia in the heart. Thyroid 19999 53-59. (https://doi. org/10.1089/thy.1999.9.53)

85 Hoit BD, Khoury SF, Shao Y, Gabel M, Liggett SB \& Walsh RA. Effects of thyroid hormone on cardiac beta-adrenergic responsiveness in conscious baboons. Circulation 199796 592-598. (https://doi. org/10.1161/01.cir.96.2.592)

86 Gick GG, Melikian J \& Ismail-Beigi F. Thyroidal enhancement of rat myocardial $\mathrm{Na}$, K-ATPase: preferential expression of alpha 2 activity and mRNA abundance. Journal of Membrane Biology 1990115 273-282. (https://doi.org/10.1007/bf01868642)

87 Boerth SR \& Artman M. Thyroid hormone regulates $\mathrm{Na}(+)$-Ca2+ exchanger expression during postnatal maturation and in adult rabbit ventricular myocardium. Cardiovascular Research 199631 E145-E152. (https://doi.org/10.1016/S0008-6363(95)00160-3)

88 Cernohorský J, Kolár F, Pelouch V, Korecky B \& Vetter R. Thyroid control of sarcolemmal $\mathrm{Na}+/ \mathrm{Ca} 2+$ exchanger and SR Ca2+-ATPase in developing rat heart. American Journal of Physiology 1998275 H264-H273. (https://doi.org/10.1152/ajpheart.1998.275.1.H264)

89 Klein I \& Ojamaa K. Thyroid hormone and the cardiovascular system. New England Journal of Medicine 2001344 501-509. (https:// doi.org/10.1056/NEJM200102153440707)

90 Kenessey A \& Ojamaa K. Thyroid hormone stimulates protein synthesis in the cardiomyocyte by activating the Akt-mTOR and p70s6K pathways. Journal of Biological Chemistry 2006281 20666-20672. (https://doi.org/10.1074/jbc.M512671200)

91 Takano AP, Diniz GP \& Barreto-Chaves ML. AMPK signaling pathway is rapidly activated by $\mathrm{T} 3$ and regulates the cardiomyocyte growth. Molecular and Cellular Endocrinology 2013376 43-50. (https://doi. org/10.1016/j.mce.2013.05.024)

92 Takano APC, Munhoz CD, Moriscot AS, Gupta S \& BarretoChaves MLM. S100A8/MYD88/NF-kB: a novel pathway involved in cardiomyocyte hypertrophy driven by thyroid hormone. Journal of Molecular Medicine 201795 671-682. (https://doi.org/10.1007/ s00109-017-1511-y)

93 Fernandez V, Barrientos X, Kipreos K, Valenzuela A \& Videla LA. Superoxide radical generation, NADPH oxidase activity, and cytochrome P-450 content of rat liver microsomal fractions in an experimental hyperthyroid state: relation to lipid peroxidation. Endocrinology 1985 117 496-501. (https://doi.org/10.1210/endo-117-2-496)

94 Asayama K, Dobashi K, Hayashibe H, Megata Y \& Kato K. Lipid peroxidation and free radical scavengers in thyroid dysfunction in the rat: a possible mechanism of injury to heart and skeletal muscle in hyperthyroidism. Endocrinology 1987121 2112-2118. (https://doi. org/10.1210/endo-121-6-2112)

95 Araujo AS, Diniz GP, Seibel FE, Bramchini G, Ribeiro MF, Brum IS, Kraper N, Barreto-Chaves ML \& Belló-Klein A. Reactive oxygen and nitrogen species balance in the determination of thyroid hormonesinduced cardiac hypertrophy mediated by renin-angiotensin system. Molecular and Cellular Endocrinology 2011333 78-84. (https://doi. org/10.1016/j.mce.2010.12.018)

96 Lino CA, Demasi M \& Barreto-Chaves ML. Ubiquitin proteasome system (UPS) activation in the cardiac hypertrophy of hyperthyroidism. Molecular and Cellular Endocrinology 2019493 110451. (https://doi.org/10.1016/j.mce.2019.110451)

97 Bilezikian JP \& Loeb JN. The influence of hyperthyroidism and hypothyroidism on - and - adrenergic receptor systems and adrenergic responsiveness. Endocrine Reviews 19834 378-388. (https://doi.org/10.1210/edrv-4-4-378)

98 Stiles GL \& Lefkowitz RJ. Thyroid hormone modulation of agonistadrenergic receptor interactions in the rat heart. Life Sciences 198128 2529-2536. (https://doi.org/10.1016/0024-3205(81)90595-6)
99 Tankeu AT, Azabji-Kenfack M, Nganou CN, Ngassam E, KuateMfeukeu L, Mba C, Dehayem MY, Mbanya JC \& Sobngwi E. Effect of propranolol on heart rate variability in hyperthyroidism. $B M C$ Research Notes 201811151 (https://doi.org/10.1186/s13104-0183224-x.)

100 Navar LG. Physiology: hemodynamics, endothelial function, reninangiotensin-aldosterone system, sympathetic nervous system. Journal of the American Society of Hypertension 20148 519-524. (https://doi. org/10.1016/j.jash.2014.05.014)

101 Skeggs LT, Kahn JR \& Shumway NP. The preparation and function of the hypertension-converting enzyme. Journal of Experimental Medicine 1956103 295-299. (https://doi.org/10.1084/jem.103.3.295)

102 Corvol P, Michaud A, Soubrier F \& Williams TA. Recent advances in knowledge of the structure and function of the angiotensin I converting enzyme. Journal of Hypertension: Supplement 199513 S3-S10. (https://doi.org/10.1097/00004872-199509003-00002)

103 Dzau VJ, Ingelfinger J, Pratt RE \& Ellison KE. Identification of renin and angiotensinogen messenger RNA sequences in mouse and rat brains. Hypertension 19868 544-548. (https://doi.org/10.1161/01. hyp.8.6.544)

104 Robertson ALJ \& Khairallah PA. Angiotensin rapid localization in nuclei of smooth and cardiac muscle. Science 1971172 1138-1139. (https://doi.org/10.1126/science.172.3988.1138)

105 Van Kats JP, Danser AH, Van Meegen JR, Sassen LM, Verdouw PD \& Schalekamp MA. Angiotensin production by the heart: a quantitative study in pigs with the use of radiolabeled angiotensins infusions. Circulation 199898 73-81. (https://doi.org/10.1161/01.cir.98.1.73)

106 Re RN. The cellular biology of angiotensin; paracrine, autocrine and intracrine actions in cardiovascular tissues. Journal of Molecular and Cellular Cardiology 198921 63-69. (https://doi.org/10.1016/00222828(89)90772-4)

107 Re RN. Mechanisms of disease: local renin-angiotensin-aldosterone systems and the pathogenesis and treatment of cardiovascular disease. Nature Clinical Practice: Cardiovascular Medicine $2004142-47$. (https://doi.org/10.1038/ncpcardio0012)

108 Vargas F, Rodríguez-Gómez I, Vargas-Tendero P, Jimenez E \& Montiel M. The renin-angiotensin system in thyroid disorders and its role in cardiovascular and renal manifestations. Journal of Endocrinology 2012213 25-36. (https://doi.org/10.1530/JOE-110349)

109 Kobori H, Ichihara A, Suzuki H, Miyashita Y, Hayashi M \& Saruta T. Thyroid hormones stimulates renin synthesis in rats without involving the sympathetic nervous system. American Journal of Physiology 1997272 E227-E232. (https://doi.org/10.1152/ ajpendo.1997.272.2.E227)

110 Kobori H, Ichihara A, Suzuki H, Takenaka T, Miyashita Y, Hayashi M $\&$ Saruta T. Role of the renin-angiotensin system in cardiac hypertrophy induced in rats by hyperthyroidism. American Journal of Physiology 1997273 H593-H599. (https://doi.org/10.1152/ ajpheart.1997.273.2.H593)

111 Machant C, Brown L \& Sernia C. Renin-angiotensin system in thyroid dysfunction in rats. Journal of Cardiovascular Pharmacology 199322 449-455. (https://doi.org/10.1097/00005344-19930900000016)

112 Sernia C, Marchant C, Brown L \& Hoey A. Cardiac angiotensin receptor in experimental hyperthyroidism in dogs. Cardiovascular Research 199327 423-428. (https://doi.org/10.1093/cvr/27.3.423)

113 Asahi T, Shimabukuro M, Oshiro Y, Yoshida H \& Takasu N. Cilazapril prevents cardiac hypertrophy and postischemic myocardial dysfunction in hyperthyroid rats. Thyroid 200111 1009-1015. (https://doi.org/10.1089/105072501753271680)

114 Basset A, Blanc J, Messas E, Hagege A \& Elghozi JL. Reninangiotensin system contribution to cardiac hypertrophy in experimental hyperthyroidism: an echocardiographic study. Journal of Cardiovascular Pharmacology 200137 163-172. (https://doi. org/10.1097/00005344-200102000-00004) 
115 Pantos C, Paizis I, Mourouzis I, Moraitis P, Tzeis S, Karamanoli E, Mourouzis C, Karageorgiou H \& Cokkinos DV. Blockade of angiotensin II type 1 receptor diminishes cardiac hypertrophy, but does not abolish thyroxin-induced preconditioning. Hormone and Metabolic Research 2005 37 500-504. (https://doi.org/10.1055/s-2005-870317)

116 Takano APC, Senger N, Munhoz CD \& Barreto-Chaves MLM. AT1 receptor blockage impairs NF-kB activation mediated by thyroid hormone in cardiomyocytes. Pflugers Archiv 2018470 549-558. (https://doi.org/10.1007/s00424-017-2088-6)

117 Carneiro-Ramos MS, Diniz GP, Nadu AP, Almeida J, Vieira RL, Santos RA \& Barreto-Chaves ML. Blockage of angiotensin II type 2 receptor prevents thyroxine-mediated cardiac hypertrophy by blocking Akt activation. Basic Research in Cardiology 2010105 325-335. (https://doi.org/10.1007/s00395-010-0089-0)

118 Schiavone MT, Santos RA, Brosnihan KB, Khosla MC \& Ferrario CM. Release of vasopressin from the rat hypothalamo-neurohypophysial system by angiotensin-(1-7) heptapeptide. PNAS $1988 \mathbf{8 5}$ 4095-4098. (https://doi.org/10.1073/pnas.85.11.4095)

119 Campagnole-Santos MJ, Diz DI, Santos RA, Khosla MC, Brosnihan KB \& Ferrario CM. Cardiovascular effects of angiotensin-(1-7) injected into the dorsal medulla of rats. American Journal of Physiology 1989 257 H324-H329. (https://doi.org/10.1152/ajpheart.1989.257.1.H324) 120 Santos RA, Brosnihan KB, Chappell MC, Pesquero J, Chernicky CL, Greene LJ \& Ferrario CM. Converting enzyme activity and angiotensin metabolism in the dog brainstem. Hypertension $1988 \mathbf{1 1}$ I153-I157. (https://doi.org/10.1161/01.hyp.11.2_pt_2.i153)

121 Donoghue M, Hsieh F, Baronas E, Godbout K, Gosselin M, Stagliano N, Donovan M, Woolf B, Robison K, Jeyaseelan R, et al. A novel angiotensin-converting enzyme-related carboxypeptidase (ACE2) converts angiotensin I to angiotensin 1-9. Circulation Research 200087 E1-E9. (https://doi.org/10.1161/01.res.87.5.e1)

122 Ye M, Wysocki J, Gonzalez-Pacheco FR, Salem M, Evora K, GarciaHalpin L, Poglitsch M, Schuster M \& Batlle D. Murine recombinant angiotensin-converting enzyme 2: effect on angiotensin II-dependent hypertension and distinctive angiotensin-converting enzyme 2 inhibitor characteristics on rodent and human angiotensinconverting enzyme 2. Hypertension 201260 730-740. (https://doi. org/10.1161/HYPERTENSIONAHA.112.198622)

123 Diniz GP, Senger N, Carneiro-Ramos MS, Santos RA \& BarretoChaves ML. Cardiac ACE2/angiotensin 1-7/Mas receptor axis is activated in thyroid hormone-induced cardiac hypertrophy. Therapeutic Advances in Cardiovascular Disease 201610 192-202. (https://doi.org/10.1177/1753944715623228)

124 Senger N, Melo MB, Diniz GP, Campagnole-Santos MJ, Santos RAS \& Barreto-Chaves MLM. Angiotensin-(1-7) reduces cardiac effects of thyroid hormone by GSK3B/NFATc3 signaling pathway. Clinical Science 2018132 1117-1133. (https://doi.org/10.1042/ CS20171606)

Received in final form 10 February 2020

Accepted 25 February 2020

Accepted Manuscript published online 26 February 2020 https://ec.bioscientifica.com https://doi.org/10.1530/EC-19-0543 (c) 2020 The authors Published by Bioscientifica Ltd
This work is licensed under a Creative Commons Attribution-NonCommercial-NoDerivatives 4.0

Internationab ticense. ifica $_{\text {. }}$. 